\title{
Parsimonious numerical modelling of deep geothermal reservoirs
}

1 Tim H. Fairs MSc, MSc, CGeol FGS Consultant Geologist, Subterra Ltd, Manchester, UK

2 Paul L. Younger PhD, CGeol FGS, CEng FICE, FREng Rankine Chair of Engineering and Professor of Energy Engineering, School of Engineering, University of Glasgow, Glasgow, UK
3 Geoff Parkin PhD

Senior Lecturer, School of Civil Engineering and Geosciences, Newcastle University, Newcastle upon Tyne, UK
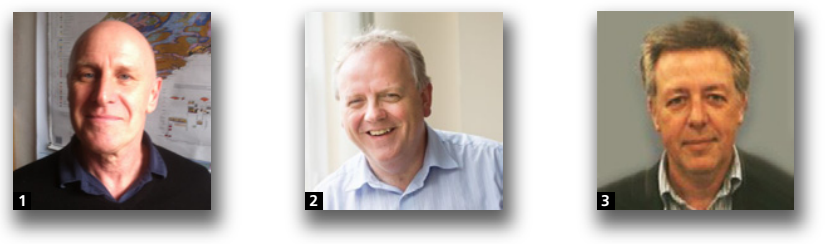

Numerical modelling has been undertaken to help improve understanding of a deep geothermal system being considered for development in the vicinity of Eastgate (Weardale, County Durham, UK). A parsimonious numerical modelling approach is used, which allows the possibility to develop a workable formal framework, rigorously testing evolving concepts against data as they become available. The approach used and results presented in this study are valuable as a contribution to a wider understanding of deep geothermal systems. This modelling approach is novel in that it utilises the mass transport code MT3DMS as a surrogate representation for heat transport in mid-enthalpy geothermal systems. A three-dimensional heat transport model was built, based on a relatively simple conceptual model. Results of simulation runs of a geothermal production scenario have positive implications for a working geothermal system at Eastgate. The Eastgate Geothermal Field has significant exploitation potential for combined heat and power purposes; it is anticipated that this site could support several tens of megawatts of heat production for direct use and many megawatts of electrical power using a binary power plant.

Notation
$c_{\mathrm{s}}$
$C_{\mathrm{ss}}$
$C^{k}$
$D_{\mathrm{h}}$
$D_{\mathrm{m}}$
$K_{\mathrm{d}}$
$n$
$q_{\mathrm{h}}$
$q_{\mathrm{ss}}$
$R$
$T$
$t$
$v_{\mathrm{a}}$
$\alpha$
$\lambda_{\mathrm{m}}$

specific heat capacity of host medium $(\mathrm{J} /(\operatorname{kg~K}))$

source or sink concentration $\left(\mathrm{kg} / \mathrm{m}^{3}\right)$ dissolved mass concentration of species $k$ $\left(\mathrm{kg} / \mathrm{m}^{3}\right)$ thermal diffusivity $\left(\mathrm{m}^{2} / \mathrm{s}\right)$ molecular diffusion coefficient $\left(\mathrm{m}^{2} / \mathrm{s}\right)$ distribution coefficient $\left(\mathrm{m}^{3} / \mathrm{kg}\right)$ porosity heat source/sink $\left(\mathrm{W} / \mathrm{m}^{3}\right)$ fluid source or sink $\left(\mathrm{s}^{-1}\right)$ retardation factor temperature $(\mathrm{K})$ time (s) specific discharge $(\mathrm{m} / \mathrm{s})$ dispersivity tensor $(\mathrm{m})$ effective thermal conductivity of the porous media $(\mathrm{W} /(\mathrm{m} \mathrm{K}))$

$\begin{array}{ll}\rho_{\mathrm{b}} & \begin{array}{l}\text { bulk density (mass of sold divided by total } \\ \text { volume })\left(\mathrm{kg} / \mathrm{m}^{3}\right)\end{array} \\ \rho_{\mathrm{m}} c_{\mathrm{m}} & \text { volumetric heat capacity of the porous } \\ & \text { medium }\left(\mathrm{J} /\left(\mathrm{m}^{3} \mathrm{~K}\right)\right) \\ & \text { volumetric heat capacity of the water } \\ \rho_{\mathrm{w}} c_{\mathrm{w}} & \left(\mathrm{J} /\left(\mathrm{m}^{3} \mathrm{~K}\right)\right)\end{array}$

\section{Introduction}

The development of engineering models for geological systems is beginning to reach considerable levels of sophistication (e.g. Parry et al., 2014). It is now widely accepted that the supreme model of any system is the conceptual model, with observational and computational models essentially serving to probe the consistency of the conceptual model with available data (cf Brassington and Younger, 2010; Konikow and Bredehoeft, 1992; Parry et al., 2014). Viewed in this light, it is never too early to establish a computational model, so that concepts can be rigorously tested for consistency with data as soon as these 
become available. Such an approach can be particularly useful in systems of complex geometry and potentially non-linear behaviour that usually defy intuitive identification of likely system responses to engineered changes. This paper reports just such an exercise: an attempt to develop a preliminary mathematical model of a deep geothermal system which has been discovered in the vicinity of Eastgate in Weardale, County Durham, UK. Additionally, this study attempts to utilise these modelling simulations to assess the capability of the well-known mass transport modelling software MT3DMS for simulating heat transport in the deep subsurface.

Two exploratory wells drilled in the Eastgate area in recent years provided the experimental database for this study. These wells targeted a high natural permeability vein/fault structure known as the Slitt Vein, that penetrates the radiothermal Weardale granite and acts as a conduit for thermal hypersaline fluids.

Limited well and regional geological data were used to construct a conceptual model of the hydrogeological system of the Eastgate area and this guided fluid flow modelling using MODFLOW and heat transport modelling using MT3DMS. MODFLOW is a modular finite difference flow model written in Fortran code that solves the general equation governing groundwater flow and is based on both Darcy's law and the law of conservation of mass (McDonald and Harbaugh, 2003). MT3DMS is a modular finite-difference three-dimensional (3D) mass transport model, widely used for simulation of contaminant transport in porous media and remediation assessment studies (Zheng and Wang, 1999). The application of MT3DMS to simulation of thermal transport phenomena in saturated aquifers is possible because the governing equations for solute transport are mathematically equivalent to those for heat transport (Hecht-Mendez et al., 2010).

The specific objectives of the study were firstly to calibrate a flow model for the Eastgate geothermal system in MODFLOW using data obtained from Eastgate boreholes 1 and 2, and then secondly, to simulate a hypothetical well doublet with a shallow injection well (Eastgate No. 1) and a deepened production well (Eastgate No. 2) in MT3DMS. This was undertaken so as to explore a sustainable production scenario over long-time periods (100 years), in order to observe any temperature decline and predict any potential thermal breakthrough from reinjected water into the production well.

While there have been previous models built of other geothermal systems, this modelling exercise is unique for the following reasons. Firstly, as it attempts to model a fault-controlled geothermal system in low-to-mid-enthalpy granite, where there is sparse data control. Secondly, it attempts to use mass transport modelling code to simulate heat transport in a deep geothermal system.

\section{Background}

\subsection{Geological setting}

The North Pennines of England has many geological and hydrogeological attributes that are favourable for the development of geothermal energy. Firstly, there is a known natural heat source at depth, namely the Weardale granite which is distinctly radiothermal. Secondly, there is an apparent plentiful supply of deep hydrothermal brines and a 'plumbing system' in the form of the Slitt Vein. Thirdly, there is a natural 'lagging' with the overlying Carboniferous Limestone and the Whin Sill dolerite, providing insulation for the system. The study area lies in the axis of Weardale, one of the principal valleys in the North Pennines, $\sim 40 \mathrm{~km}$ west southwest of the city of Durham. The geological features of interest at Eastgate form part of the North Pennine Orefield, a regionally uplifted and domed structure comprising of a series of horst blocks (Kimbell et al., 2010) (Figure 1).

\subsection{Geothermal developments}

In addition to the mineralisation that is associated with the North Pennine Batholith, recent interest has concentrated on its geothermal potential, with investigations of the hydrogeologically active fracture systems, specifically the Slitt Vein in the Eastgate area (Manning et al., 2007).

\subsection{Eastgate drilling/testing history}

Exploration for this geothermal resource commenced in December 2004 with the drilling of Eastgate No. 1 well, reaching a total depth of $995 \mathrm{~m}$. The well trajectory was designed to track the Slitt Vein and associated splays vertically downwards for up to $1 \mathrm{~km}$ (Figure 2). The borehole successfully penetrated $723 \mathrm{~m}$ of Weardale granite, overlain by $272 \mathrm{~m}$ of Quaternary and Lower Carboniferous cover rocks. At $410 \mathrm{~m}$ depth, a major open fissure was encountered, which was assumed to be a splay fault associated with the Slitt Vein. The borehole received a large influx of warm formation water, with a high electrical conductivity. Alkali geothermometry was conducted on water samples, suggesting that the water achieved equilibrium with respect to $\mathrm{Na}, \mathrm{K}$ and $\mathrm{Ca}$ at depths of between 3 and $4 \mathrm{~km}$, based on a geothermal gradient of $40^{\circ} \mathrm{C} / \mathrm{km}$. This is a significant point, as it implies that the formation water encountered possibly forms part of a deep circulation system that appears to be still active (Manning et al., 2007).

Following the drilling of the Eastgate No. 1 borehole, extensive hydraulic testing was carried out during March 2006. In the first phase, the entire open section of the borehole from 403 to $995 \mathrm{~m}$ depth was test pumped at a rate of $888 \mathrm{~m}^{3} / \mathrm{d}$. The pumping rate during the second phase of testing in the lower 


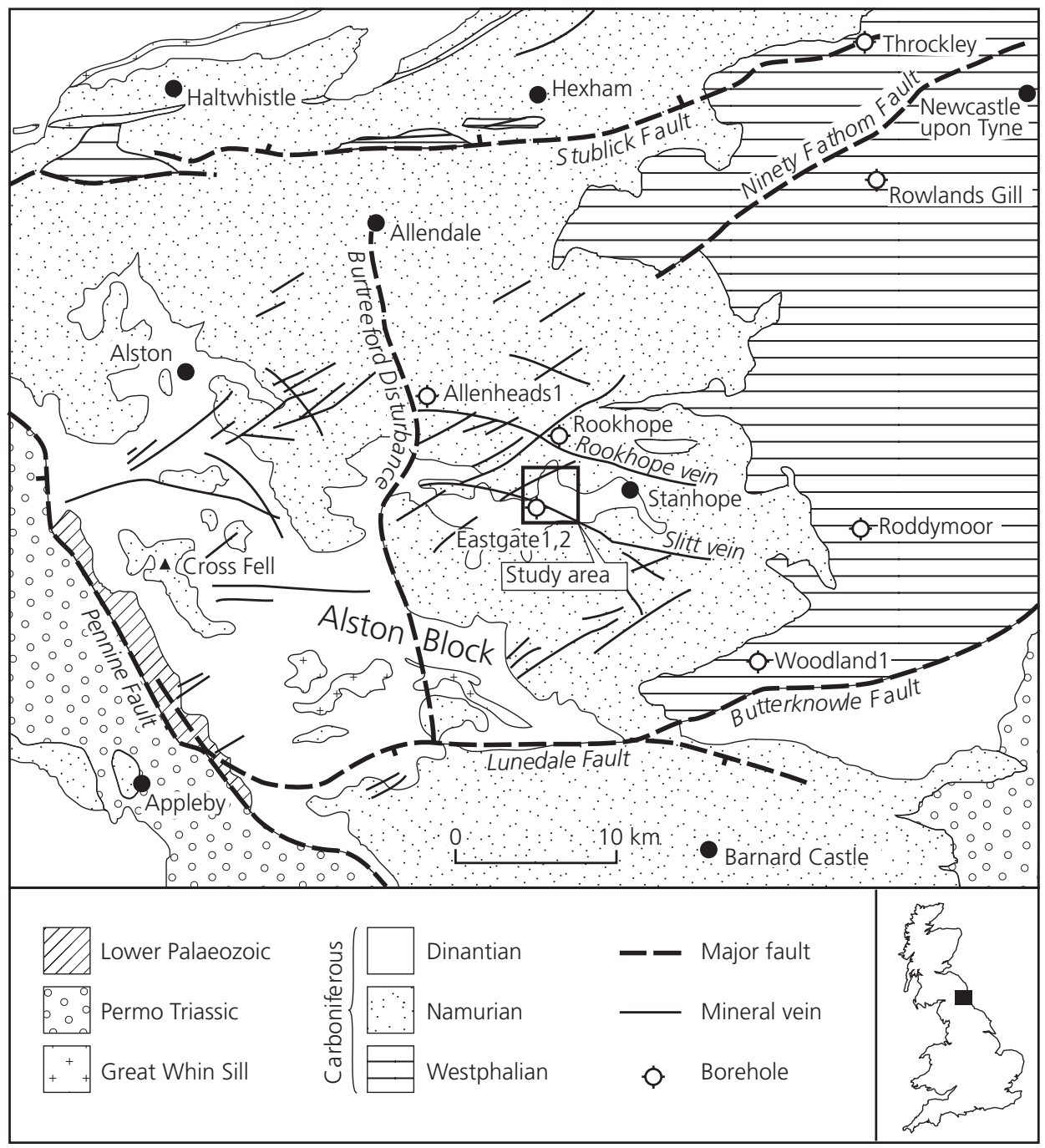

Figure 1. Geological map of the North Pennines of England (simplified after Kimbell et al. (2010))

fracture zone of the granite below $431 \mathrm{~m}$ was $518 \mathrm{~m}^{3} / \mathrm{d}$. The pumping tests and their respective drawdown were revealing as the first test suggested that the flow was by way of the Slitt Vein, whereas the hydraulic response from the second test suggested that the lower fracture system was not in hydraulic connection with the Slitt Vein (Younger and Manning, 2010). These test results also confirmed the high permeability of the Slitt Vein, with an intrinsic transmissivity in excess of 4000 darcy $m$.

The Eastgate No. 2 borehole was drilled in March 2010 to a total depth of $420 \mathrm{~m}$ and successfully penetrated $134 \mathrm{~m}$ of Weardale granite, in addition to $286 \mathrm{~m}$ of recent and Lower Carboniferous cover rocks. The Weardale granite at this location was found to be hydraulically tight, with an average intrinsic transmissivity of around 6 darcy $\mathrm{m}$, obtained from a rising head test. This was in line with expectations, as Eastgate No. 2 was located $300 \mathrm{~m}$ from the Slitt Vein and thus, confirmed the high permeabilities in Eastgate No. 1 as being due to the borehole intercepting the Slitt Vein.

\section{Conceptual modelling - a tripartite modelling approach}

The first critical step in the process of constructing a robust numerical model is to establish a conceptual model or a theory-based description that satisfies the various boundary conditions and assumptions made with regard to 


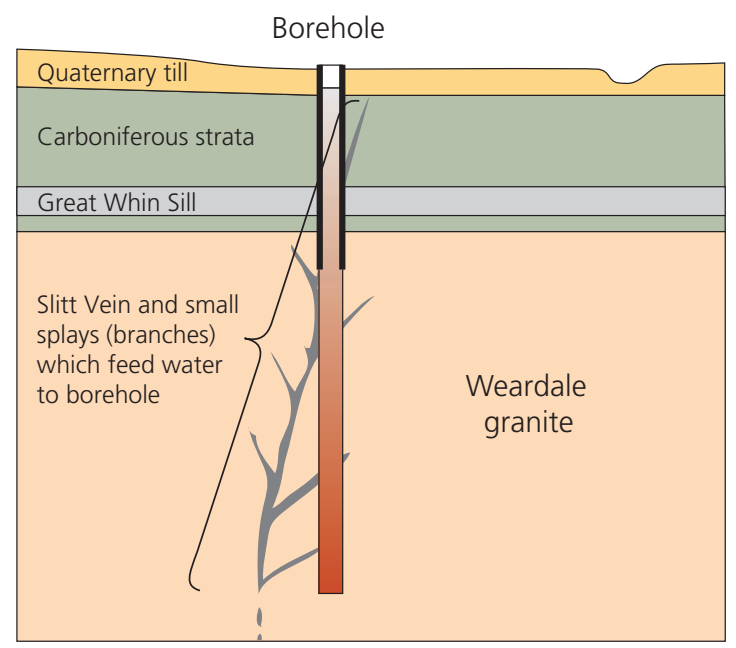

Figure 2. Schematic diagram of cross-section of Eastgate Borehole No. 1 (after Manning et al., 2007)

the hydrogeological processes (Brassington and Younger, 2010).

This conceptual model attempts to define the Eastgate geothermal system that essentially consists of a fracture-hosted hydrothermal brine circulation system, represented in this study area as the Slitt Vein, cross-cutting the Weardale granite in a west northwest to east southeast orientation. Fluid and heat flow are assumed to be predominantly along the main Slitt Vein, with associated splays and fractures deeper within the Weardale granite providing a secondary conduit as observed from the Eastgate No. 1 pump test results. Apart from convective heat transport, there is also thought to be a contribution from conductive heat transport through the host granite, which will be discussed further in Section 3.3. The Weardale granite is overlain unconformably and blanketed by over $270 \mathrm{~m}$ of Lower Carboniferous strata, including the Whin Sill, which are also intersected by the Slitt Vein fracture system to the surface. No recharge was included in the model, but sensitivity to recharge is considered later in section 4.2. The model contains the two Eastgate wells - Eastgate No. 1 is considered as a shallow injection well and Eastgate No. 2, deepened in the model to intersect the Slitt Vein at $2500 \mathrm{~m}$, acts as a production well.

In terms of model domain size, the horizontal dimensions were chosen as $3000 \mathrm{~m} \times 3000 \mathrm{~m}$, in consideration of the radii of influence of the two boreholes, along with a vertical depth of $3000 \mathrm{~m}$ that covers the deepened production well at Eastgate No. 2.

A modelling strategy was adopted that began with a very simple model containing only the Slitt Vein, with geological

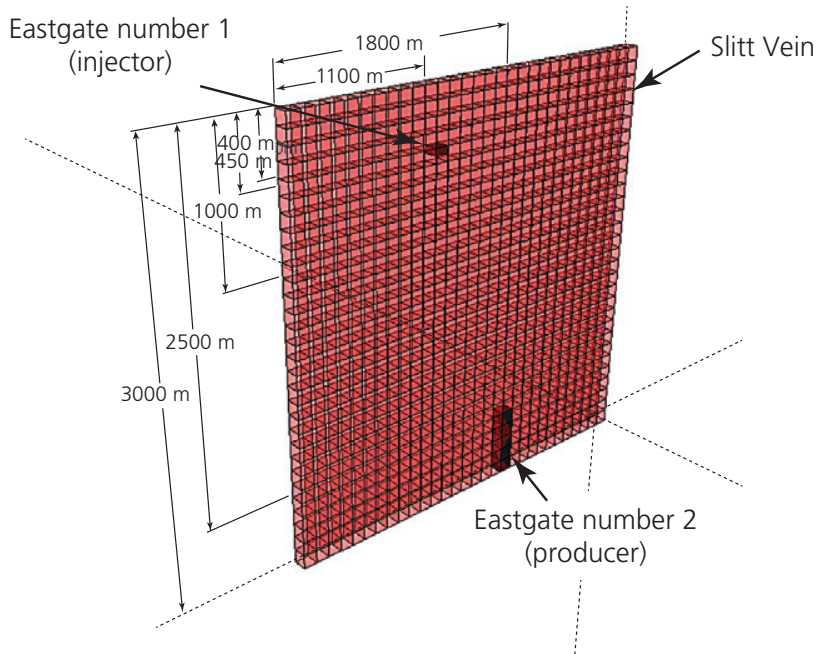

Figure 3. Two-dimensional Slitt Vein model showing intersection of Eastgate well No. 1 (injector) and deepened Eastgate well No. 2 (producer) as shaded cells

and hydrogeological complexity progressively added to the model, with respect to the surrounding fracture zone and the host granitic body. This approach led to the creation of a tripartite modelling process, whereby the first model is a twodimensional (2D) representation of only the Slitt Vein, the second is a $3 \mathrm{D}$ 'limited-extent' model that includes a fracture zone surrounding the Slitt Vein and the third is a $3 \mathrm{D}$ 'full-extent' model that includes the main granitic host (Figures 3-5, respectively); these are discussed in more detail below.

\subsection{Fluid flow modelling (MODFLOW)}

\subsubsection{Two-dimensional Slitt Vein model}

This model is a relatively simple $2 \mathrm{D}$ representation of only the Slitt Vein that is assumed to be vertical and with the two Eastgate wells intersecting the vein at discrete intervals (Figure 3). The major assumption of this model is that active flow only occurs within the Slitt Vein. The model grid consists of a single row of 30 cells of total length $3000 \mathrm{~m}$ and an individual cell size of $100 \mathrm{~m}$. It has a total vertical depth of $3000 \mathrm{~m}$ and a layering scheme that conforms generally to the major stratigraphic horizons, as well as the zones of intersection of the two Eastgate boreholes with the Slitt Vein. The model was run first in steady state with the Eastgate No. 1 well set as a producer at a rate of $888 \mathrm{~m}^{3} / \mathrm{d}$, so that an attempt could be made to calibrate the model against the drawdown results reported from the testing. The model was then simulated as a well doublet system, with Eastgate No. 1 acting as an injector and a deepened Eastgate No. 2 as a producer, both pumping at $888 \mathrm{~m}^{3} / \mathrm{d}$. 


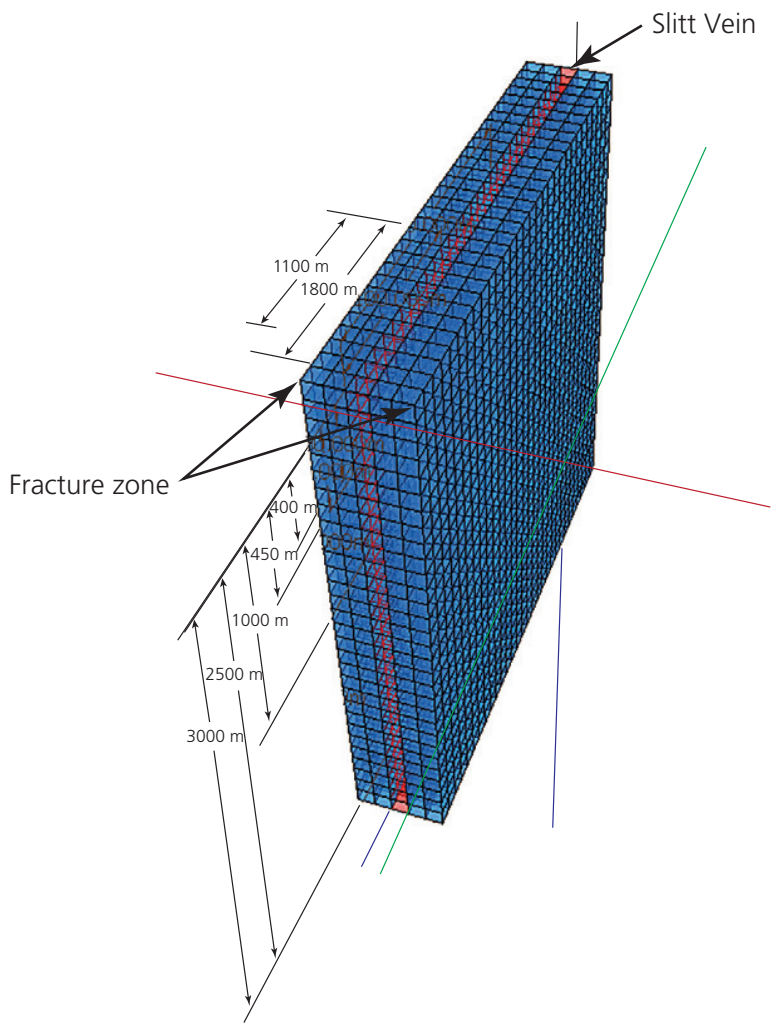

Figure 4. Three-dimensional limited-extent model showing Slitt Vein with surrounding fracture zone of enhanced permeability

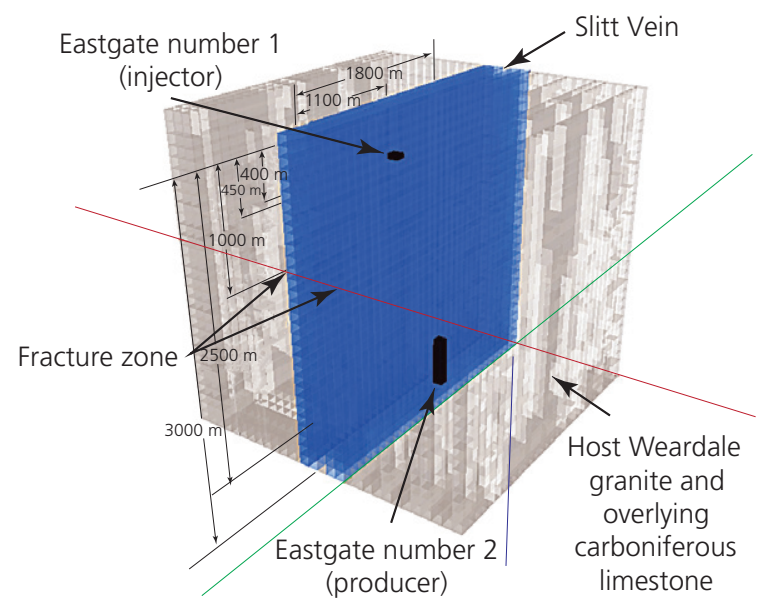

Figure 5. Three-dimensional full-extent model showing Slitt Vein with surrounding fracture zone of enhanced permeability, and host Weardale granite and Carboniferous Limestone. Well intersection intervals for Eastgate well Nos. 1 and 2 into the Slitt Vein are indicated as shaded cells

\subsubsection{Three-dimensional limited-extent model}

This model comprises the 2D Slitt Vein model surrounded by a limited $200 \mathrm{~m}$ zone of enhanced permeability within the fractured host granite and overlying Carboniferous Limestone (Figure 4). The major assumption of this model is that active flow occurs mainly within the Slitt Vein, but with a contribution from the surrounding fracture zone. As with the 2D Slitt Vein model, the 3D limited-extent model was calibrated against the drawdown results reported from the first test phase. Calibration of the model was also carried out using the drawdown results from the second test phase for the lower $500 \mathrm{~m}$ interval within the surrounding fracture zone. However, the well intersections were limited to the Slitt Vein for the well doublet scenario, with Eastgate No. 1 acting as an injector and Eastgate No. 2 as a producer, as described previously.

\subsubsection{Three-dimensional full-extent model}

This model comprises the Slitt Vein and surrounding limitedextent enhanced permeability fracture zone surrounded by a much larger volume of the host granite and overlying Carboniferous Limestone that have negligible permeability (Figure 5). The major assumption of this model is that the host granite beneath the blanket of Carboniferous Limestone is effectively impermeable, but that this large volume of rock may be significant in the modelling if it is a major contributory factor as a heat source. The model grid consists of $1250 \mathrm{~m}$ of the host country rock laterally on either side of the Slitt Vein/ fracture zone. In terms of model calibration and simulation, the same procedures were applied as for the previously described 3D limited-extent model.

\subsection{Fluid flow calibration results (MODFLOW)}

Calibration was carried out by attempting to match the model drawdown values with the observed drawdown values from the two Eastgate No. 1 well tests. Drawdown is defined as the difference between the initial water level in a given well and the observed water level at any specific time during a period of pumping. Model drawdown was varied by changing the value of the hydraulic conductivity parameter. Horizontal and vertical hydraulic conductivities were both initially set as equal for all cells in the model and based on values reported from the hydraulic responses from Eastgate No. 1 testing results (Younger and Manning, 2010). This approach to calibration can be considered as a form of inverse modelling or parameter identification. This is analogous to pumping test analysis, where radial flow represented by an analytical equation is used to determine transmissivity and hence, hydraulic conductivity. For this study, a different geometrical configuration is represented, but the response is similarly controlled by the ability of the active flow zones to convey flow rates that are affected primarily by the hydraulic conductivity and the zone widths. Hence, the drawdown response is sensitive to both hydraulic 


\begin{tabular}{lcccrr} 
Model & $\begin{array}{c}\text { Well test } \\
\text { drawdown: } m\end{array}$ & $\begin{array}{c}\text { Initial model } \\
\text { drawdown: } m\end{array}$ & $\begin{array}{c}\text { Initial hydraulic } \\
\text { conductivities: m/d }\end{array}$ & $\begin{array}{c}\text { Revised hydraulic } \\
\text { conductivities: m/d }\end{array}$ & $\begin{array}{r}\text { Final model } \\
\text { drawdown: } m\end{array}$ \\
\hline Two-dimensional Slitt Vein & 0.5 & 0.0013 & 3200 & 320 & 0.5 \\
Three-dimensional limited extent & $27 \cdot 0$ & 0.0016 & $3200 / 170$ & $3 \cdot 2 / 0 \cdot 17$ & 1.9 \\
Three-dimensional full extent & $27 \cdot 0$ & 0.0004 & $3200 / 170 / 21$ & $320 / 17 / 0 \cdot 21$ & $12 \cdot 0$
\end{tabular}

Table 1. Fluid flow model calibration (hydraulic conductivity values represent the zones Slitt Vein/fracture zone/host rock)

conductivity and the assumptions of the geometry and extent of the active flow zones as represented in the models.

Table 1 summarises calibration results for the three models. It can be observed that the initial model drawdowns were very small in comparison with the well test drawdowns, and that significant changes were required in the hydraulic conductivity values in order to get a reasonable match. The numbers in the columns for the initial and revised hydraulic conductivities relate to the values that were used for the specific zones of the model in question. The difficulty in achieving equivalent drawdown values reflects the challenges of both optimising model parameters whilst at the same time reconciling the complexity of the fracture network in this system.

Despite this, it should be appreciated that a match within the same order of magnitude is considered reasonable when dealing with hydraulic conductivity; this can naturally vary over several orders of magnitude for a given rock type in water-supply aquifers (Younger, 2007). In addition, it was difficult to obtain a 'typical' value for hydraulic conductivity for comparison purposes due to the unique nature of this environment.

\subsection{Heat transport modelling (MT3DMS)}

MT3DMS uses the following partial differential equation to solve for solute transport in transient groundwater flow systems (Zheng and Wang, 1999)

1.

$$
\begin{aligned}
\left(1+\rho_{\mathrm{b}} K_{\mathrm{d}} / n\right) \partial C^{k} / \partial t= & \operatorname{div}\left[\left(D_{\mathrm{m}}+\alpha_{V_{\mathrm{a}}}\right) \operatorname{grad} C^{k}\right] \\
& -\operatorname{div}\left({ }_{V_{\mathrm{a}}} C^{k}\right)+q_{\mathrm{ss}} C_{\mathrm{ss}} / n
\end{aligned}
$$

Equation 1 is the general governing equation for solute transport.

The left-hand side of the equation is the product of the transient term and the retardation factor $(R)$, where $R=\left(1+\rho_{\mathrm{b}} K_{\mathrm{d}} / n\right)$. For solute transport, retardation is caused by adsorption of solutes by the aquifer matrix material. On the right-hand side of the equation, the first term defines hydrodynamic dispersion, which includes pure molecular diffusion $\left(D_{\mathrm{m}}\right)$ and mechanical dispersion $\left(\alpha_{V_{\mathrm{a}}}\right)$. The second term defines advection and the third term defines the source and sink processes.

The heat transport equation invokes the second law of thermodynamics (i.e. conservation of thermal energy in this case), considering both conduction and convection (De Marsily, 1986), and can be simplified to the following form (HechtMendez et al., 2010)

2.

$$
\begin{gathered}
\left(\rho_{\mathrm{m}} c_{\mathrm{m}} / n \rho_{\mathrm{w}} c_{\mathrm{w}}\right) \cdot \partial T / \partial t=\operatorname{div}\left[\left(\lambda_{\mathrm{m}} / n \rho_{\mathrm{w}} c_{\mathrm{w}}+\alpha_{V_{\mathrm{a}}}\right) \operatorname{grad} T\right] \\
-\operatorname{div}\left(V_{\mathrm{a}} T\right)+q_{\mathrm{h}} / n \rho_{\mathrm{w}} c_{\mathrm{w}}
\end{gathered}
$$

Equation 2 is the general governing equation for heat transport.

In comparing the two above equations, coefficients needed for heat transport can be readily substituted for their solute transport counterparts, so that MT3DMS can be used without modification to model heat transport. The following coefficients are described with their implementation in MT3DMS, as originally detailed in Hecht-Mendez et al. (2010).

Retardation factor $(R)$ and the distribution coefficient $\left(K_{\mathrm{d}}\right)$ in the solute transport equation represent solute adsorption by the aquifer matrix; so in the heat transport equation, retardation is a result of heat transfer between the fluid and solid aquifer matrix. MT3DMS represents thermal retardation by calculating the distribution coefficient $\left(K_{\mathrm{d}}\right)$ for the temperature species as a function of thermal properties as follows: $K_{\mathrm{d}}=c_{\mathrm{s}} /$ $\rho_{\mathrm{w}} c_{\mathrm{w}}$, where $c_{\mathrm{s}}$ is the specific heat capacity of the solids and $\rho_{\mathrm{w}} c_{\mathrm{w}}$ is the volumetric heat capacity of the water.

The value for the distribution coefficient is input in MT3DMS in the 'Chemical Reaction Package', as the slope of the isotherm, with the type of sorption set to 'linear isotherm' (ISOTHM =1), so that the temperature exchange rate between the solid and water is independent of any temperature changes.

As described above, there are two parts in the solute transport equation to describe hydrodynamic dispersion; molecular 
diffusion $\left(D_{\mathrm{m}}\right)$ and mechanical dispersion $\left(\alpha_{V_{\mathrm{a}}}\right)$. Heat conduction is mathematically equivalent to molecular solute diffusion. Whereas in solute transport, molecular diffusion is a function of the concentration gradient, in heat transport it is a function of the temperature gradient and is equivalent to the following: $D_{\mathrm{h}}=\lambda_{\mathrm{m}} / n \rho_{\mathrm{w}} c_{\mathrm{w}}$.

This value is input in MT3DMS in the 'Dispersion Package' as the molecular diffusion coefficient (DMCOEF). The terms for hydrodynamic dispersion $\left(\alpha_{V_{\mathrm{a}}}\right)$ describe the differences in flow velocity at a pore scale; the specific dispersivity coefficients in MT3DMS are longitudinal dispersivity and the ratios of transverse horizontal and vertical dispersivity to longitudinal dispersivity. These coefficients are directly applied and input as heat dispersivity coefficients for heat transport in MT3DMS.

In the heat transport equations, the source and sink term represents heat input or extraction, and the temperature value (K) is equivalent to concentration $\left(\mathrm{kg} / \mathrm{m}^{3}\right)$. Therefore, temperature is substituted directly for concentration as 'Source/Sink' with the type of source set to 'Well' (ITYPE0=1).

Table 2 lists heat transport variables with the values used as initial input in the numerical codes in MT3DMS for the modelling.

\subsection{Assumptions and limitations of modelling approach}

Table 3 is a summary of the main assumptions made in the modelling process, coupled with comments in terms of the resultant limitations to the modelling effort. It is envisaged that as the implications of these limitations are recognised, these can then guide further study, which will be discussed later in Section 6 of this paper.

\section{Well doublet production scenario}

\subsection{Heat transport simulation results (MT3DMS)}

A well doublet production scenario was simulated with a transient state model in MT3DMS, using the flow simulation from the 3D full-extent model in MODFLOW. The heat transport simulation was run over a 100-year period, with temperature values monitored at two discrete points in the model; these were $200 \mathrm{~m}$ west of the Eastgate No. 1 (injector) and Eastgate No. 2 (producer) wells, respectively. It was observed that the temperature monitored in close proximity to the injector well (Eastgate No. 1) showed an overall $5-6^{\circ} \mathrm{C}$ decrease in temperature for the 100-year time period, with temperature monitored nearby to the producer well (Eastgate No. 2) showing a larger decrease in temperature of $14^{\circ} \mathrm{C}$ during this time period (Figures 6 and 7). The lower part of Figure 6 is a crosssectional view along the Slitt Vein axis for this simulation at the end of 10 years and shows both Eastgate wells. It can be seen that the isotherms are relatively undisturbed across the model, except in the area of the Eastgate No. 1 well, where the model appears to be showing some perturbation by the reinjection of cooler water at $293 \mathrm{~K}$. The upper part of Figure 6 shows a time-series plot for the model covering the entire time period of 100 years, with temperature measured at the cell $200 \mathrm{~m}$ to the west of the Eastgate No. 1 injector well. It can be seen from the decline curve of the plot that the temperature decrease is more rapid at first and then levels-off around

\begin{tabular}{|c|c|c|c|c|}
\hline Symbol & Variable & Value & Units & Reference source \\
\hline$\overline{K_{d}}$ & Distribution coefficient & $2 \cdot 10 \times 10^{-4}$ & $\mathrm{~m}^{3} / \mathrm{kg}$ & \\
\hline$\lambda_{\mathrm{m}}$ & $\begin{array}{l}\text { Effective thermal conductivity of the host rock } \\
\text { (granite/Carboniferous Limestone) }\end{array}$ & $3 \cdot 4$ & $\mathrm{~W} /(\mathrm{m} \mathrm{K})$ & $\begin{array}{l}\text { Banks (2008: p. 35) } \\
\text { Downing and Gray (1986) }\end{array}$ \\
\hline$n$ & Porosity & 0.05 & - & Younger (personal communication) \\
\hline$\rho_{\mathrm{m}} C_{\mathrm{m}}$ & Volumetric heat capacity of granite/limestone & $2.4 \times 10^{+6}$ & $\mathrm{~J} /\left(\mathrm{m}^{3} \mathrm{~K}\right)$ & Banks (2008: p. 35) \\
\hline$\rho_{\mathrm{w}} C_{\mathrm{w}}$ & Volumetric heat capacity of water & $4 \cdot 18 \times 10^{+6}$ & $J /\left(m^{3} K\right)$ & Hecht-Mendez et al. (2010) \\
\hline$c_{S}$ & Specific heat capacity of host (Weardale granite) & 845 & $\mathrm{~J} /(\mathrm{kg} \mathrm{K})$ & Downing and Gray (1986) \\
\hline$\alpha_{1}$ & Longitudinal dispersivity & $0 \cdot 5$ & $\mathrm{~m}$ & Hecht-Mendez et al. (2010) \\
\hline$\alpha_{\mathrm{th}}$ & Transverse horizontal dispersity & $0 \cdot 5$ & $\mathrm{~m}$ & Hecht-Mendez et al. (2010) \\
\hline$\alpha_{\mathrm{tv}}$ & Transverse vertical dispersity & $0 \cdot 5$ & $\mathrm{~m}$ & Hecht-Mendez et al. (2010) \\
\hline$D_{\mathrm{h}}$ & Thermal diffusivity & $2.97 \times 10^{-6}$ & $\mathrm{~m}^{2} / \mathrm{s}$ & \\
\hline$R$ & Retardation factor & $2 \cdot 29$ & - & \\
\hline \multirow[t]{3}{*}{$\rho_{\mathrm{b}}$} & Dry bulk density of host rock & 1690 & $\mathrm{~kg} / \mathrm{m}^{3}$ & Downing and Gray (1986) \\
\hline & Injection temperature & 293 & K & Younger (personal communication) \\
\hline & Geothermal gradient & 38 & ${ }^{\circ} \mathrm{C} / \mathrm{km}$ & Manning et al. (2007) \\
\hline
\end{tabular}

Table 2. Heat transport variables, values, units and reference sources 
Assumptions

1 Subsurface geology is understood

2 Conceptual model is comprehensive

3 Model dimensions are appropriate

4 Boundary conditions are appropriate

5 Subsurface fluid flow is almost entirely from the Slitt Vein

6 Recharge is uniform temporally and areally

7 Recharge is solely from precipitation

8 Porosity distribution is uniform

9 Hydraulic conductivity and permeability is isotropic

10 Heat transport modelling using MT3DMS is appropriate for use in deep geothermal systems
Limitations

Subsurface geology could be much more complex, in terms of faulting/fracturing and orientation of Slitt Vein, along with connectivity. Only one geological model is considered here

Model may not have all potential boundary conditions and flow directions considered

Model may not be sufficiently large to capture all flow and heat transport volumes

Model may not have correct boundary conditions in terms of flux

Significant fluid and heat transport may be coming from host granite by way of a larger fracture system

Recharge may vary areally and temporally which will affect the flow budget in the model

Recharge could be from surface run-off and indirectly by way of flooded mine workings

Fracture porosity may not be evenly distributed

Hydraulic conductivity may be anisotropic and heterogeneous

MT3DMS is run decoupled from MODFLOW, which may cause significant errors due to temperature variations affecting water viscosity and density, which in turn affect hydraulic conductivity

Table 3. Assumptions and limitations of modelling process

$20000 \mathrm{~d}$ (54.8 years), with the temperature stabilising around $293 \mathrm{~K}\left(20^{\circ} \mathrm{C}\right)$. The lower part of Figure 7 is a crosssectional view along the Slitt Vein axis for this simulation at the end of 100 years, showing both Eastgate wells. It can be seen that by this time, the isotherms have been extensively disrupted throughout, particularly in the area around the abstraction well (Eastgate No. 2). The upper part of Figure 7 shows a time-series plot for the entire time period of 100 years for the cell $200 \mathrm{~m}$ to the west of the Eastgate No. 2 abstractor well. It can be seen that the temperature decrease appears to be linear over this time period.

\subsection{Sensitivity analysis}

Sensitivity analysis gives an increased understanding of the relationship between input and output variables in a model and helps to identify the inputs that cause the most uncertainty in the outputs; these should then be key areas for study if confidence in a model is to be achieved.

A summary of the results of the sensitivity analysis is shown in Figure 8 in the form of a tornado diagram (this is a useful and graphical way of showing the relative importance or sensitivity of input variables to the output variable, which in this case is the temperature change $(\Delta K))$. The chosen temperature value is at a nominal model cell location, $300 \mathrm{~m}$ to the west of Eastgate No. 1 well at the end of $7330 \mathrm{~d}(20 \cdot 1$ years). The input variables were all systematically varied from a range of $-50 \%$ to $+2000 \%$ and the output variable, in this case the change in temperature $(\Delta K)$, at the designated point in the model was recorded.

It can be interpreted from the results of the sensitivity analysis shown in Figure 8 that the inputs likely to cause the most uncertainty in the outputs in the model are, in order of decreasing significance, recharge, distribution coefficient $\left(K_{\mathrm{d}}\right)$, porosity and hydraulic conductivity.

\section{Discussion and conclusion}

A steady-state 3D flow model was constructed in MODFLOW and calibrated with observed drawdowns from the Eastgate boreholes. A transient state $3 \mathrm{D}$ heat transport model was constructed in MT3DMS and simulation runs indicate significant temperature decreases around the area of the producer well, with a slow linear decline in temperature over time. In contrast, the temperature around the injector well shows an initial rapid decline, which then stabilises to the injection temperature. These results from the heat transport simulations have positive implications and significance for a potential working geothermal production system operating under these conditions, as thermal decline is predicted to be sufficiently slow at the producer well, with no apparent thermal breakthrough from the injector well over the 100 -year time period in which the model was run. The majority of heat transport in this model appears to occur within the Slitt Vein due to a combination of convective and conductive processes. 


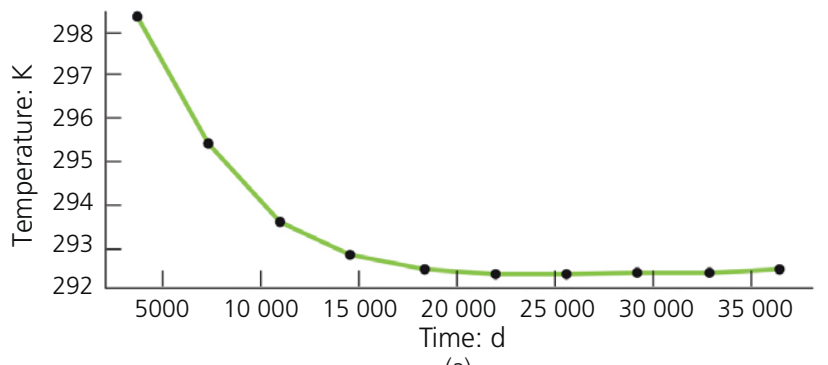

(a)

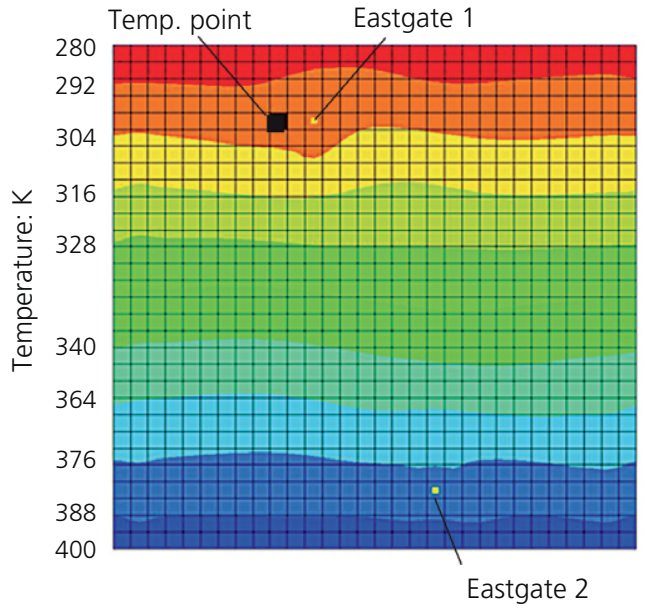

(b)

Figure 6. (a) Time-series plot for the model covering 100 years, with temperature measured at the cell $200 \mathrm{~m}$ to the west of the Eastgate No. 1 injector well. (b) Cross-sectional view along Slitt Vein axis at the end of 10 years ( $3650 \mathrm{~d}$ ). Eastgate wells and temperature measurement point indicated. Note that the numbers on the $y$-axis in (b) are temperature contour labels, and each square spatially represents $100 \mathrm{~m}$

Sensitivity analysis indicates that the heat transport model is most sensitive to parameters representing convective transport - those governing pore water velocities such as recharge, hydraulic conductivity, porosity and local heat exchange between water and rock. It is less sensitive to parameters related to large-scale conductive heat transport such as distribution coefficient, thermal diffusivity and dispersivity. This is a good example of a generic finding from this study which has wider applicability.

Through parsimonious numerical modelling, a self-consistent 'model' (in its general sense) of the behaviour of this type of environment has been developed, both in terms of process understanding and for quantifying appropriate parameters. In doing so, this modelling work contributes to the building of a portfolio of evidence, though at the present time this is very limited due to a scarcity of available datasets for equivalent

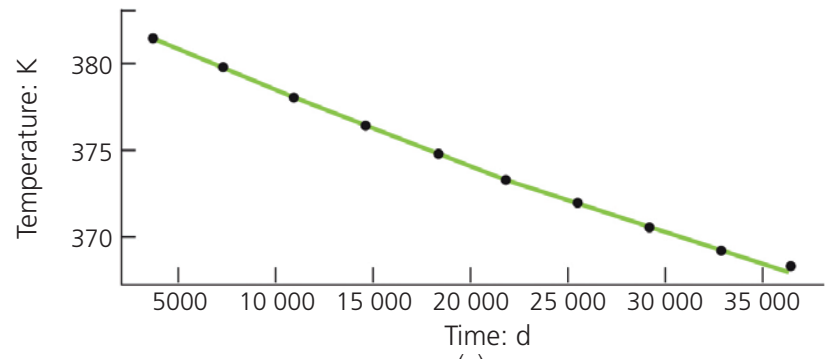

(a)

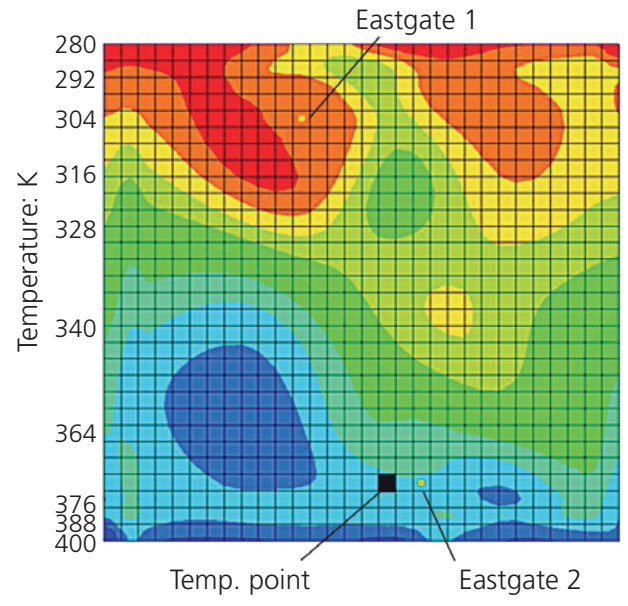

(b)

Figure 7. (a) Time-series plot for the model covering 100 years, with temperature measured at the cell $200 \mathrm{~m}$ to the west of the Eastgate No. 2 producer well. (b) Cross-sectional view along Slitt Vein axis at the end of 100 years (36 $500 \mathrm{~d}$ ). Eastgate wells and temperature measurement point indicated.

Note that the numbers on the $y$-axis in (b) are temperature contour labels, and each square spatially represents $100 \mathrm{~m}$.

geothermal systems. This makes this work all the more important not only in terms of its contribution through the methodology of the exploratory modelling approach, but also in the interpreted hydraulic conductivity values. It is also timely in terms of helping to inform future engineering strategies for developing deep geothermal energy.

This type of model cannot be proven or validated, it can only be tested and invalidated (Konikow and Bredehoeft, 1992). The most one can ever ask is that one achieves credible consistency between concepts, that is, those used to establish the model and the available data (cf Brassington and Younger, 2010; Parry et al., 2014). It is believed that this has been generally achieved in this model. First, the concept of heat and fluid flow concentrated along a high permeability fault system was corroborated with the results of the drawdown calibrations. Second, the results of the sensitivity analysis indicated that the 


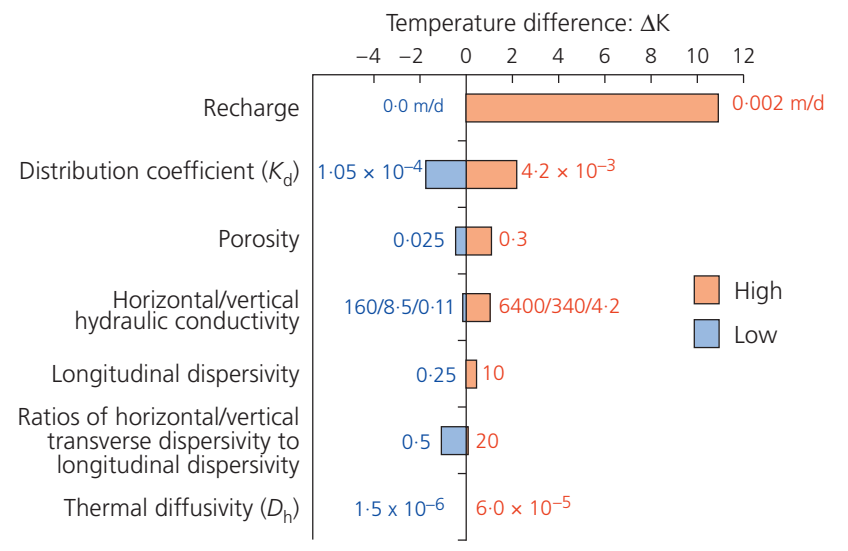

Figure 8. Tornado diagram showing sensitivity of model input parameters to output parameter of temperature change $(\Delta K)$. The chosen temperature value is at a model cell location, $300 \mathrm{~m}$ to the west of Eastgate No. 1 well at the end of $7330 \mathrm{~d}$ ( $20 \cdot 1$ years). Note that the low and high legend entries relate to parameter value extremes. Units are as in Table 2

heat transport model is most sensitive to parameters related to convective heat transport and this supports the model of faultrelated heat and fluid flow.

The modelling approach is valid for other circumstances, precisely because it is physically based - that is, it is based on the physics of the system. There is no reason why a similar faultassociated geothermal system could not be modelled using the same approach. Site-specific parameters are, of course, site specific, but the approach is generically valid.

\section{Recommendations for future work}

In addition to gaining more raw data to help the modelling, there are a number of issues surrounding assumptions made in this initial model that need to be addressed in future modelling. These are described below.

The assumption that heat transport modelling using MT3DMS is appropriate for use in deep geothermal systems has limitations and is clearly an area for further study, as any large temperature variation will affect water viscosity and density, which in turn affects hydraulic conductivity. These changes are not taken account of as MT3DMS is decoupled from MODFLOW. Fracture heterogeneity is clearly an issue that requires further study and future work in this area may involve constructing various geostatistical models to attempt to capture the variability inherent in this property, to support simulations in which permeability is allowed to be heterogeneous. In terms of the sensitivity analysis, work has been carried out to date and this could be taken further in terms of carrying out predictive sensitivity analysis. This would involve selecting variations of a particular scenario based on the sensitivity analysis and then running these as a range of simulations. Another important piece of future work could be the calculation of the Peclet number for a range of models, which would reflect convection and conduction-dominated scenarios; this would be very useful in terms of understanding the relative importance and implications of these heat transport processes. Finally, the current model was run over what was considered a sufficiently long time period of 100 years, but more simulation runs could be made for longer periods, to observe what further thermal decline occurs.

As and when further resources become available to develop the Eastgate Geothermal Field, the model presented here supports the notion that it could be exploited in combined heat and power mode to produce several tens of megawatts of direct-use heat, as well as many megawatts of electrical power by deployment of a binary power plant operating according to the principles of the organic Rankine cycle or similar approaches (cf Younger, 2013; Younger et al., 2012).

This paper has practical relevance and potential application for any civil engineer interested in the quantification and feasibility of an area for prospective geothermal production assessment; the modelling techniques described in this paper could be readily adopted and employed for other systems.

\section{Acknowledgements}

This paper is based on work undertaken by the first author for a dissertation submitted as part of an MSc in Applied Hydrogeology at Newcastle University. The authors acknowledge funding of the Eastgate fieldwork from One NorthEast, the Geothermal Challenge Fund of the UK Government's Department of Energy and Climate Change, and helpful suggestions from Cluff Geothermal Ltd on field data interpretation, and funding from the Natural Environment Research Council (NERC grant number NE/I018905/2) for part of the geological work used to underpin the modelling. The assistance of Christine Jeans at Newcastle University in preparing the figures is gratefully acknowledged.

\section{REFERENCES}

Banks D (2008) An Introduction to Thermogeology: Ground Source Heating and Cooling. Wiley-Blackwell, London, UK.

Brassington FC and Younger PL (2010) A proposed framework for hydrogeological conceptual modelling. Water and Environment Journal 24(4): 261-273.

De Marsily G (1986) Quantitative Hydrogeology. Academic Press, Orlando, FL, USA. 
Downing RA and Gray DA (1986) Geothermal Energy. The Potential in the United Kingdom. British Geological Survey, H.M. Stationary Office, London, UK.

Hecht-Mendez J, Molina-Giraldo N, Blum P and Bayer P (2010) Evaluating MT3DMS for heat transport simulation of closed geothermal systems. Ground Water 48(5): 741-756.

Kimbell GS, Young B, Millward D and Crowley QG (2010) The North Pennine batholith (Weardale granite) of northern England: new data on its age and form. Proceedings of the Yorkshire Geological Society 58(2): 107-128.

Konikow LF and Bredehoeft JD (1992) Ground-water models cannot be validated. Advances in Water Resources 15(1): 75-83.

Manning DAC, Younger P, Smith FW et al. (2007) A deep geothermal exploration well at Eastgate, Weardale, UK: a novel exploration concept for low-enthalpy resources. Journal of the Geological Society, London 164(2): 371-382.

McDonald MG and Harbaugh AW (2003) The history of MODFLOW. Ground Water 41(2): 280-283.

Parry S, Baynes FJ, Culshaw MG et al. (2014) Engineering geological models: an introduction: IAEG commission 25. Bulletin of Engineering Geology \& the Environment 73(3): 689-706.

Younger PL (2007) Groundwater in the Environment: An Introduction. Blackwell, Oxford, UK.
Younger PL (2010) Geothermal Borehole Works at Eastgate, County Durham Undertaken in 2010 with funding from the Deep Geothermal Challenge Fund. Department of Energy and Climate Change, London, UK, Final Report.

Younger PL (2013) Renewable heat and binary power: the contribution of deep geothermal energy. Keynote Lecture. Proceedings of the 13th UK Heat Transfer Conference (UKHTC2013), 2nd-3rd September 2013, Imperial College, London, UK.

Younger PL and Manning DAC (2010) Hyper-permeable granite: lessons from test-pumping in the Eastgate Geothermal Borehole, Weardale, UK. Quarterly Journal of Engineering Geology and Hydrogeology 43(1): 5-10.

Younger PL, Gluyas JG and Stephens WE (2012) Development of deep geothermal resources in the UK. Proceedings of the Institution of Civil Engineers - Energy 165(EN1): 19-32, http://dx.doi.org/10.1680//ener.11.00009.

Zheng C and Wang PP (1999) MT3DMS: A Modular Three Dimensional Multi-species Transport Model for Simulation of Advection, Dispersion and Chemical Reactions of Contaminants in Groundwater Systems; Documentation and User's Guide. US Army Corps of Engineers Research and Development Center, Vicksburg, MS, USA, p. 202, Contract Report SERDP-99-1. See http://hydro.geo.ua.edu/mt3d/ (accessed 02/07/2015).

\section{WHAT DO YOU THINK?}

To discuss this paper, please email up to 500 words to the editor at journals@ice.org.uk. Your contribution will be forwarded to the author(s) for a reply and, if considered appropriate by the editorial panel, will be published as discussion in a future issue of the journal.

Proceedings journals rely entirely on contributions sent in by civil engineering professionals, academics and students. Papers should be 2000-5000 words long (briefing papers should be 1000-2000 words long), with adequate illustrations and references. You can submit your paper online via www.icevirtuallibrary.com/content/journals, where you will also find detailed author guidelines. 